\title{
"Ease of use, security concerns and attitudes as antecedents of customer satisfaction in ATM banking"
}

\begin{tabular}{|c|c|}
\hline AUTHORS & $\begin{array}{l}\text { Hilda Bongazana Dondolo (D http://orcid.org/0000-0002-5978-1708 } \\
\text { Nkosivile Welcome Madinga (D https://orcid.org/0000-0003-4026-7423 }\end{array}$ \\
\hline ARTICLE INFO & $\begin{array}{l}\text { Hilda Bongazana Dondolo and Nkosivile Welcome Madinga (2016). Ease of use, } \\
\text { security concerns and attitudes as antecedents of customer satisfaction in ATM } \\
\text { banking. Banks and Bank Systems, 11(4-1), 122-126. doi:10.21511/bbs.11(4- } \\
\text { 1).2016.02 }\end{array}$ \\
\hline DOI & http://dx.doi.org/10.21511/bbs.11(4-1).2016.02 \\
\hline RELEASED ON & Thursday, 22 December 2016 \\
\hline JOURNAL & "Banks and Bank Systems" \\
\hline FOUNDER & LLC "Consulting Publishing Company "Business Perspectives" \\
\hline & $\begin{array}{l}\text { ニ-:- } \\
\text { E=:- }\end{array}$ \\
\hline NUMBER OF REFERENCES & NUMBER OF FIGURES \\
\hline 0 & 0 \\
\hline
\end{tabular}

(C) The author(s) 2023. This publication is an open access article. 
Hilda Bongazana Dondolo (South Africa), Nkosivile Welcome Madinga (South Africa)

\title{
Ease of use, security concerns and attitudes as antecedents of customer satisfaction in ATM banking
}

\begin{abstract}
This study examines the influence of ease of use, security concerns and attitudes on South African consumers' satisfaction with ATM banking services. Participants of the study were solicited through electronic mailing list of ATM users in South Africa. These participants were provided with a website link that directed them to an online survey hosted by Qualtrics. A total of 224 participants from the various provinces of South Africa responded. This study confirms that customer satisfaction is linked to security concerns, attitudes and ease of use. Overall, the results indicate that the respondents were satisfied with ATM banking services. Since there is a shortage of research on customer satisfaction with ATM banking services in South Africa, an area often neglected by South African researchers, this study contributes to knowledge available in the existing literature.
\end{abstract}

Keywords: ATM banking, customer satisfaction, ease of use, security, attitudes. JEL Classification: G21, M31.

\section{Introduction}

If there is one sector that uses technology more than any other and that has more customer complaints, it is the banking sector. This phenomenon is observed globally. As such, the banking sector has continually added new time saving technologies in their environments. One such technology is the Automated Teller Machines (ATM). However, even with these advancements, customers still complain and are often angry and frustrated and, at times, raising serious concerns that the technology provided by banks might not take into consideration their banking requirements (Jayawardhena \& Foley, 2000; Haron, Ahmad \& Planisek, 1994). Many of the frustrations stem from a number of factors including long queues and waiting time (Greenland, Coshall \& Combe, 2006). Whether these queues reflect inefficiencies in the ATM technology itself or the failure of the banks to deliver satisfactory customer service, is unclear. What appears to be a consensus among researchers, however, is that customers' experience with these queues have been found to exert powerful influence on their satisfaction. Thus, when it comes to services offered at the banking sector, customers hope that banks would not only meet their expectations, but also would exceed such expectations. On the basis of this statement, those organizations that exceed customer expectations, will generally see a reduction in customer complaints (Fornell \& Wernerfelt, 1987). Thus, well managed customer expectations have been found to mitigate complaints and, as a result, lead to customer satisfaction (Shankar, Smith \& Rangaswamy, 2003).

(C) Hilda Bongazana Dondolo, Nkosivile Welcome Madinga, 2016. Hilda Bongazana Dondolo, Dr., Tshwane University of Technology, Department of Integrated Communication, Faculty of Humanities, South Africa.

Nkosivile Welcome Madinga, Mr., AAA School of Advertising, Department of Integrated Marketing Communication, Faculty of Marketing, Cape Town Campus, South Africa.
On the surface, the concept of customer satisfaction appears to be simple. Typically, customers use this concept when they describe their approval of the service. However, satisfaction is more complicated with numerous definitions associated with it. Oliver (1997) describes satisfaction as a pleasurable fulfilment of certain needs, desires and goals. Anderson (1994) noted that satisfaction is based on what the customer expects of a service and what is, in fact, delivered. It is for this reason that Hallowell (1996) concluded that customer satisfaction arises when customers perceive value from a particular exchange relationship or transaction.

What is noteworthy is that, in the banking sector, literature identifies a number of variables influencing customer satisfaction depending on the banking technology used. However, there are no specific factors attributed to customer satisfaction in the ATM banking environment. Previous research has identified a myriad of factors such as systems availability, fulfilment and efficiency, security and responsiveness, easiness, cost effectiveness, social benefits, functional benefits, ease of use, speed and so forth. If the notion of the above-mentioned variables typifies the determinants of customer satisfaction in the banking sector, as indicated in previous research, and if we want to address customer satisfaction with ATM banking services, especially in a country like South Africa, then, the question is: what are the determinants of customer satisfaction with ATM banking services in South Africa? The country has seen a marked increase in ATMs. At the end of 2015, there were 26000 reported ATM machines, 2 percent higher than 2011. With this growth in ATMs, there appears to be limited amount of research addressing customer satisfaction with this technology. Therefore, the aim of this study is to emphasize how attitudes towards ATM banking, ease of use and security concerns affect customer satisfaction. 


\section{Conceptual model and hypotheses develop- ment}

There are many ideas of what might cause customer satisfaction with ATM banking services. Of the many factors identified in literature, this study focuses on ease of use, security concerns and attitudes. Figure 1 presents the proposed conceptual model of the factors affecting customer satisfaction with ATM banking services.

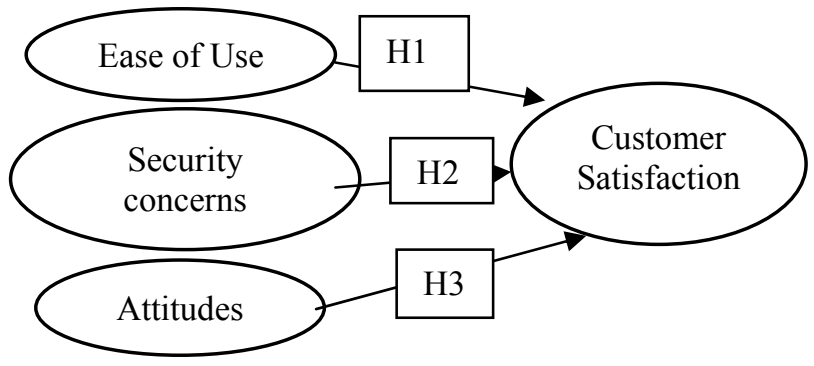

Fig. 1. Proposed factors influencing customer satisfaction with ATM banking services

Hypotheses formulation. In this paper, three hypotheses are formulated.

Ease of use. A customer's perceptions of the effort expended in a particular technology serves as a decision as to whether they will use that particular technology or not. It is generally believed that customers may choose to use banking technology if they believe it is easy to use. Venkatesh (2000) refers to this notion as ease of use and describes it as the extent in which one believes that using a particular technology will be without effort. In the present study, if a customer suggests that an ATM might facilitate the performance of transactions with minimum effort, then, they may come to believe that it is easy to use. Therefore, the following is hypothesized:

$H_{1}$ : There is a positive significant relationship between ease of use and customer satisfaction with ATM banking services.

Security concerns. The security concerns that are increasing rapidlyand are somewhat related to the use of any technology in the banking sector. These concerns, unless addressed, have been found to influence customer satisfaction with the technology. Thus, customers who report concerns on security issues report lower levels of customer satisfaction. This notion was supported by Murugiah and Akgam (2015) when they observed a negative relationship between security and customer satisfaction in their respondents. This meant that their respondents had higher security concerns which resulted in lower levels of customer satisfaction. In the context of ATM banking services, security may be described as customers' perceptions of the safety of the ATM when performing transactions (Chang \& Chen, 2009). The above arguments led to the following hypothesis:
H2: Security is negatively and significantly related to customer satisfaction with ATM banking services.

Attitudes. Attitudes have been defined in many ways. However, a person's attitude is based on what they expect the object, institution or another person would do and links those expectations to what was actually delivered (Zeithaml, Berry \& Parasuraman, 1993). In the context of technology, attitudes have been studied by many authors, including Davis, Bagozzi and Warshaw (1989), Venkatesh (2000), Koufaris and Hampton-Sosa (2002), Pikkarainen, Pikkarainen, Karjaluoto and Pahnila (2004), among others, and have been found to affect an individual's evaluations and is a predictor of the use of technology, especially in the banking environment (Khawaja \& Manarvi, 2009). Also, attitudes serve as an indicator of the level of satisfaction within that sector (Moutinho \& Smith, 2000). Therefore, this paper hypothesizes that:

H3: There is a significant and positive relationship between attitudes and customer satisfaction with ATM banking services.

\section{Method}

Participants and procedure. Participants of the study were solicited through an electronic mailing list of ATM users in South Africa. These participants were provided with a website link that directed them to an online survey hosted by Qualtrics. Participants were asked to answer questions that solicited their demographics and questions with items measuring ease of use, attitudes, security and customer satisfaction. A total of 224 participants responded. Table 1 presents the demographic profile of respondents.

Table 1. Demographics of respondents (\%)

\begin{tabular}{|c|c|c|}
\hline & & Total \\
\hline \multirow[t]{2}{*}{ Gender } & Female & 49 \\
\hline & Male & 51 \\
\hline \multirow[t]{5}{*}{ Age } & $18-25$ years & 18 \\
\hline & $26-35$ & 18 \\
\hline & $36-45$ & 14 \\
\hline & $46-55$ & 17 \\
\hline & $56+$ & 33 \\
\hline \multirow[t]{4}{*}{ Education } & High school & 39 \\
\hline & FET qualification & 34 \\
\hline & Undergraduate degree & 11 \\
\hline & Postgraduate degree & 16 \\
\hline \multirow[t]{7}{*}{ Employment } & Full-time employment & 58 \\
\hline & Part-time employment & 5 \\
\hline & Self-employed & 13 \\
\hline & Unemployed & 3 \\
\hline & Housewife & 4 \\
\hline & Student & 8 \\
\hline & Pensioner & 9 \\
\hline
\end{tabular}


Measuring instrument. The questionnaire was developed by using scales from previous studies. Perceived ease of use and attitudes toward ATM usage were adapted from the study by Davis (1989). The security concerns scale was adapted from a scale developed by Brown, Fuller and Vician (2004). To assess customer satisfaction, items adapted from Sierra, Heiser and McQuitty (2009) were used. The items of the measuring instrument were measured in a 6-point Likert scale from 1 (strongly disagree) to 6 (strongly agree). The measuring instrument was then subjected to a reliability test using Cronbach alpha. All the alpha scores were above the suggested $0.70-0.90$ (Nunnally \& Bernstein, 1994) cut-off points. The security construct returned a 0.671 alpha value. Satisfaction, attitude and ease of use returned $0.895,0.946$ and 0.840 alpha values, respectively. Overall, the measuring scales of the instrument of the current study were all reliable.

Data analysis and results. In this paper, the mean values, standard deviations and correlation and regression analysis were performed. Table 2 shows the mean values, standard deviations and correlation matrix of the factors influencing customer satisfaction with ATM banking services.

Table 2. Mean, standard deviation and correlation matrix

\begin{tabular}{|l|c|c|c|c|c|c|c|}
\hline Constructs & N & Mean & $\begin{array}{c}\text { Standard } \\
\text { deviation }\end{array}$ & Security & Satisfaction & Attitudes & $\begin{array}{c}\text { Ease of } \\
\text { use }\end{array}$ \\
\hline Security & 224 & 3.55 & 1.54 & 1 & $-0.290^{* *}$ & $-0.217^{* *}$ & $-0.162^{*}$ \\
\hline Satisfaction & 224 & 4.91 & 0.95 & $-0.29^{* *}$ & 1 & $0.698^{* *}$ & $0.681^{* *}$ \\
\hline Attitudes & 224 & 5.02 & 1.07 & $-0.217^{* *}$ & $0.698^{* *}$ & 1 & $0.600^{* *}$ \\
\hline $\begin{array}{l}\text { Ease of } \\
\text { use }\end{array}$ & 224 & 5.31 & 0.73 & $-0.162^{*}$ & $0.681^{* *}$ & $0.600^{* *}$ & 1 \\
\hline
\end{tabular}

Significant at $* \mathrm{p}<0.05,{ }^{* *} \mathrm{p}<0.01$ (2-tailed).

From the table above, ease of use and attitudes had the highest mean scores $\mathrm{M}=5.31, \mathrm{~S}=0.73$ and $\mathrm{M}=5.02, \mathrm{~S}=1.070$ respectively, indicating that the respondents of this study believe that ease of use and attitudes are more important in determining customer satisfaction with ATM banking services. Security concerns recorded the lowest mean score $(\mathrm{M}=3.55, \mathrm{~S}=1.54)$, indicating that the respondents of this study slightly disagree that security plays a role in customer satisfaction.

Correlations for the constructs of this study were also computed. The results in Table 3 indicate that there is a positive relationship between satisfaction and attitudes $(\mathrm{r}=0.698, \mathrm{p}<0.01)$, suggesting that respondents who were satisfied with ATM banking services were likely to have positive attitudes towards it. Also, there was a positive relationship between ease of use and satisfaction $(\mathrm{r}=0.681, \mathrm{p}<0.01)$ indicating that those respondents who found the ATM banking easy to use are likely to be satisfied with it. A positive relationship between ease of use and attitudes $(r=0.600$, $\mathrm{p}<0.01)$ was also observed, indicating that those respondents who find ATM banking easy to use are likely to have a positive attitude towards it. However, the results show a negative relationship between security and satisfaction $(\mathrm{r}=-0.290, \mathrm{p}<0.01)$, security and attitudes $(\mathrm{r}=-0.217, \mathrm{p}<0.01)$ and security and ease of use $(\mathrm{r}=-0.162, \mathrm{p}<0.05)$. This suggests that those respondents who had high security concerns were likely to be less satisfied with the services offered by ATM banking. Also, those respondents who had high security concerns were likely to find the use of ATMs less easy to use and, consequently, develop negative attitudes towards ATM banking. Therefore, the results of the correlation analysis confirm the existence of a relationship among the constructs of ATM banking customer satisfaction.

Regression analysis. To test the hypothesized relationships among the constructs, regression analysis was used. About 61 percent of total variance in customer satisfaction is explained by ease of use, security and attitudes $\left(\mathrm{R}^{2}=0.61, \mathrm{~F}=115.493, \mathrm{p}<0.05\right)$, showing support for the hypothesized relationships. Table 3 shows support for all the hypotheses.

Table 3. Regression analysis

\begin{tabular}{|l|c|c|c|c|}
\hline \multicolumn{1}{|c|}{$\begin{array}{c}\text { Predictor } \\
\text { variables }\end{array}$} & $\begin{array}{c}\text { Standardized } \\
\text { Coefficients }\end{array}$ & T values & $\begin{array}{c}\text { Significance } \\
\text { level }\end{array}$ & Decision \\
\hline Security & -1.33 & -3.078 & 0.002 & Supported \\
\hline Attitudes & 0.427 & 8.034 & 0.000 & Supported \\
\hline Ease of use & 0.404 & 7.688 & 0.000 & Supported \\
\hline
\end{tabular}

Significant at $\mathrm{p}<0.05$ level.

As shown in Table 3, ease of use showed a significant relationship with customer satisfaction with ATM banking services $(\beta=0.404, p<0.05)$. This was consistent with hypothesis 1 . On the other hand, respondents' security concerns were negatively related $(\beta=-1.33$, $\mathrm{p}<0.05)$ to their satisfaction with ATM banking services. Thus, hypothesis 2 was supported. There was a significant positive relationship between attitudes and customer satisfaction $((\beta=0.427, \mathrm{p}<0.05)$. Therefore, hypothesis 3 was supported. Since all hypotheses were accepted, this indicates that security concerns, attitudes and ease of use are significant determinants of customer satisfaction with ATM banking services among the South African consumers.

\section{Discussion and conclusion}

The purpose of this study was to assess South African consumers' satisfaction with ATM banking services. This study specifically looked at the associations between customer satisfaction with ATM banking services and security, attitudes and ease of use. The results of the study are consistent with previous studies on the banking sector. The results indicate that the respondents who believe ATM banking is easy to use were more satisfied with the services offered by this 
technology. Kadir, Rahmani and Masinaei (2011) also found similar results when they showed that ease of use, in their study referred to as ease of navigation, influenced their respondents' level of satisfaction with ATM banking. The results of Moutinho and Smith (2000) indicated that, in their study, those respondents who had positive attitudes towards ATMs were more likely to be satisfied with it. Our results are similar to the findings of Moutinho and Smith (2000). As in the findings of Kumbhar (2011) who found a relationship between security and customer satisfaction, our study also found such relationship with customer satisfaction. Kumbhar (2011) further suggested that banks should concentrate on security to satisfy customers, which also stresses the importance of security to banks.

The study contributed to the existing body of literature by testing variables used in technology adoption model (namely, ease of use and attitudes) and a variable used in studying online technologies (security) to assess South African consumers' satisfaction with ATM banking services. The results indicate that South African consumers are satisfied with ATM banking services. The findings suggest that customers, i.e., those respondents who were satisfied with ATM banking found it easy to use; and that resulted in positive attitudes towards ATM banking services. These respondents also indicated that they will be more satisfied with ATMs when the security of the ATMs is strengthened.

We have identified limitations to this study. The study tested few factors influencing customer satisfaction in the banking environment. It would be interesting to understand whether customers would be satisfied with ATM banking even if they perceive no value derived from such technology. Therefore, future research should test for a relationship between perceived benefits and customer satisfaction. Lastly, this study was conducted in South Africa. Therefore, it is difficult to generalize the findings across cultures. The South African banking environment presents its own unique challenges that might differ from those of other countries.

There has been prevalence of ATM skimming, bombings leading Price Waterhouse Cooper (2016) and to conclude that criminality and technology risk are of huge concern for South African banks.

This study offers recommendations to South African banks. We recommend stringent security measures. Also, to protect the user's pin from skimming devices inserted in ATMs, biometric system is recommended.

\section{References}

1. Anderson, E.W. (1994). Cross-category variation in customer satisfaction and retention, Marketing Letters, 5 (1), pp. 19-30.

2. Brown, S.A., Fuller, R.M. \& Vician, C. (2004). Who's afraid of the virtual world? Anxiety and computer-mediated communication, Journal of the Association for Information Systems, 5 (2), pp. 79-107.

3. Chang, H.H., \& Chen, S.W. (2009). Consumer perception of interface quality, security, and loyalty in electronic commerce, Information \& Management, 46 (7), pp. 411-417.

4. Davis, F.D., Bagozzi, R.P. \& Warshaw, P.R. (1989). User acceptance of computer technology: a comparison of two theoretical models, Management Science, 35 (8), pp. 982-1003.

5. Fornell, C. \& Wernerfelt, B. (1987). Defensive marketing strategy by customer complaint management: a theoretical analysis, Journal of Marketing Research, 24 (4), pp. 337-346.

6. Greenland, S., Coshall, J. \& Combe, I. (2006). Evaluating service quality and consumer satisfaction in emerging markets. International Journal of Consumer Studies, 30 (6), pp. 582-590.

7. Hallowell, R. (1996). The relationships of customer satisfaction, customer loyalty, and profitability: an empirical study, International Journal of Service Industry Management, 7 (4), pp. $27-42$.

8. Haron, S., Ahmad, N. \& Planisek, S.L. (1994). Bank patronage factors of Muslim and non-Muslim customers, International Journal of Bank Marketing, 12 (1), pp. 32-40.

9. Jayawardhena, C. \& Foley, P. (2000). Changes in the banking sector-the case of Internet banking in the UK, Internet Research, 10 (1), pp. 19-31.

10. Kadir, H.A., Rahmani, N. \& Masinaei, R. (2011). Impacts of service quality on customer satisfaction: Study of Online banking and ATM services in Malaysia. International Journal of Trade, Economics and Finance, 2 (1), p. 1.

11. Khawaja, K.F. \& Manarvi, I. (2009). Evaluating customer perceptions towards ATM services in financial institutions; a case study of Pakistani banks. Proceedings of the conference in Computers \& Industrial Engineering, 2009, CIE39. France, pp.1440-1445.

12. Koufaris, M. \& Hampton-Sosa, W. (2002). Customer trust online: examining the role of the experience with the Web-site. Department of Statistics and Computer Information Systems Working Paper Series, Zicklin School of Business, Baruch College, New York.

13. Kumbhar, V. (2011). Factors affecting on customers' satisfaction an empirical investigation of ATM service. International Journal of Business Economics and Management Research, 2 (3), pp. 144-156.

14. Moutinho, L. \& Smith, A. (2000). Modelling bank customer satisfaction through mediation of attitudes towards human and automated banking, International Journal of Bank Marketing, 18 (3), pp. 124-134.

15. Murugiah, L. \& Akgam, H.A. (2015). Study of Customer Satisfaction in the Banking Sector in Libya, Journal of Economics, Business and Management, 3 (7), pp. 674-677. 
16. Nunnally, J.C., Bernstein, I.H. (1994). Psychometric theory. (3rd ed.). New York: McGraw-Hill.

17. Oliver, R.L. (1997). Satisfaction: a Behavioral Perspective on the Customer. New York: McGraw-Hill.

18. Pikkarainen, T., Pikkarainen, K., Karjaluoto, H. \& Pahnila, S. (2004). Consumer acceptance of online banking: an extension of the technology acceptance model, Internet Research, 14 (3), pp. 224-235.

19. Price Waterhouse Cooper. (2016). Growing in turbulent times: Major banks analysis - South Africa. https://www.pwc.co.za/en/assets/pdf/major-banks-analysis-march-2016. [date of access: 12 October 2016].

20. Shankar, V., Smith, A.K. \& Rangaswamy, A. (2003). Customer satisfaction and loyalty in online and offline environments, International Journal of Research in Marketing, 20 (2), pp. 153-175.

21. Sierra, J.J., Heiser, R.S., \& McQuitty, S. (2009). Exploring determinants and effects of shared responsibility in service exchanges, Journal of Marketing Theory and Practice, 17 (2), pp. 111-128.

22. Venkatesh, V. (2000). Determinants of perceived ease of use: Integrating control, intrinsic motivation, and emotion into the technology acceptance model, Information Systems Research, 11 (4), pp. 342-365.

23. Zeithaml, V.A., Berry, L.L. \& Parasuraman, A. (1993). The nature and determinants of customer expectations of service, Journal of the Academy of Marketing Science, 21 (1), pp. 1-12. 